\title{
Formiminotransferase Deficiency Syndrome Associated with Megaloblastic Anemia Responsive to Pyridoxine or Folic Acid*
}

\author{
Tsuneo Arakawa, Tsunenobu Tamura, Ototaka Higashi, Kazuo Ohara, \\ Kaneo Tanno, Yoshiyuki Honda, Kuniaki Narisawa, Tasuke Konno, \\ Yoshiro Wada, Yasushi Sato and Takashi Mizuno \\ Department of Pediatrics (Prof. Ts. Arakawa), \\ Faculty of Medicine, Tohoku University, Sendai
}

\begin{abstract}
A third case of formiminotransferase deficiency syndrome was described, which was associated with megaloblastic-pyridoxine-folic acid-responsive anemia of probably congenital origin. The occurrence of megaloblastic pyridoxine-folic acid-responsive anemia was not observed in two cases of formiminotransferase deficiency syndrome previously reported by us.
\end{abstract}

Formiminotransferase deficiency syndrome ${ }^{1,2}$ was firstly discovered by us as a new inborn error of folate metabolism which was characterized by 1) mental retardation, 2) hyperfolic acidemia, and 3) an excessive urinary excretion of formiminoglutamic acid (FIGLU) following an oral dose of L-histidine. A definite diagnosis of this syndrome was established by demonstrating a defective activity of formiminotransferase in the liver specimens obtained from patients in question.

The purpose of our present paper is to describe an infant with formiminotransferase deficiency syndrome associated with megaloblastic-pyridoxine-folic acidresponsive anemia probably of congenital origin.

\section{Report of Case}

Y.A., a three-month-old boy was admitted to the University Hospital on February 7, 1966, because of pallor developing soon after birth. The patient was the only child of healthy and nonconsanguineous parents. Pregnancy and delivery were uneventful and the birth weight was $2,600 \mathrm{~g}$. Neonatal history revealed nothing abnormal except for pallor of the skin. His appetite was good and there was no history of diarrhea or vomiting.

At 15 days of life examination of peripheral blood was made at a local hospital and revealed that red cell count was $212 \times 10^{4} / \mathrm{mm}^{3}$, hemoglobin $44 \%$ and white blood cell count $7,500 / \mathrm{mm}^{3}$. At that hospital from the 17 th day of life onward,

Received for publication, August 14, 1967.

* Supported in part by a grant of National Institute of Child Health and Human Development, HD 01505-03, U.S.A. 
vitamin $\mathrm{B}_{12}, 500 \gamma$ daily, was given intramuscularly for a 4-day period, in addition to blood transfusions in a daily dose of $50 \mathrm{ml}$ for consecutive 10 days. The anemia seemed to be improved following the therapy, but a relapse of anemia ensued two months later.

When 3 months old the patient was referred to the University Hospital for further evaluation of the anemia noted soon after birth.

Physical examination revealed a pale boy with a slightly distended abdomen. Auscultation on the lungs and heart gave no abnormality. The liver was palpable two finger breadths under the costal margin and soft in consistence. The spleen was not palpable. There was no lymphadenopathy. Deep tendon reflexes were normal and no pathologic reflexes were elicited. X-ray films of the chest, extremities and skull revealed no abnormality. The circumference of the head measured $39 \mathrm{~cm}$, that of the chest $40 \mathrm{~cm}$, body length $56 \mathrm{~cm}$ (normal $60.9 \mathrm{~cm}$ ) and bodyweight $5.34 \mathrm{~kg}$ (normal $6.3 \mathrm{~kg}$ ).

\section{Laboratory findings}

Urine was negative for bile, acetone and protein and for the $\mathrm{FeCl}_{3}$ test, but slightly positive to Benedict's reaction on several occasions. The centrifuged sediments were clear except for 3 to 6 white cells per a high-power field.

Thin layer chromatography of urinary amino acids revealed no abnormality.

Liver function tests including CCFT, ZTT, GOT, GPT and alkaline phosphatase remained within normal limits on repeated examinations during his stay in the hospital.

Serum electrolytes were found to be normal except that serum iron levels were ranging from 135 to $202 \gamma / 100 \mathrm{ml}$ before pyridoxine therapy was instituted, and decreased to the levels from $46 \gamma / 100 \mathrm{ml}$ to $53 \gamma / 100 \mathrm{ml}$ after pyridoxine administration.

Serum phospholipids and total lipids were normal, but serum cholesterol was ranging from $64 \mathrm{mg} / 100 \mathrm{ml}$ to $80 \mathrm{mg} / 100 \mathrm{ml}$ before pyridoxine therapy and slightly increased to the levels of $80 \mathrm{mg} / 100 \mathrm{ml}(\mathrm{Jan} .6,1967)$ and of $102 \mathrm{mg} / 100 \mathrm{ml}$ (May 4,1967 ) after the pyridoxine therapy.

Serum levels of $\beta$-lipoprotein were estimated by Heiskell et al.'s method ${ }^{3}$ and were found to be of markedly lower values of $0.9 \mathrm{~mm}$ (Oct. 1966) and $0.9 \mathrm{~mm}$ (March 1967), as compared with those of normal infants $(2.3-3.5 \mathrm{~mm}$ ).

L-Tryptophan loading test: L-tryptophan, $100 \mathrm{mg}$ per $\mathrm{kg}$ of bodyweight, was given and 24 hours' urine specimens were collected and estimated for urinary pyridone and xanthurenic acid, and subjected to paperchromatographic analysis of other tryptophan metabolites. Urinary pyridone ${ }^{4}$ was found to be $31 \mu$ moles $/ 24 \mathrm{hr} / \mathrm{kg}$ and $169 \mu$ moles $/ 24 \mathrm{hr} / \mathrm{kg}$ before and after the oral dose of $\mathrm{L}$ tryptophan, respectively. Urinary excretion of xanthurenic acid ${ }^{5}$ was $4.6 \mu$ moles/ $24 \mathrm{hr} / \mathrm{kg}$ and $2.7 \mu$ moles $/ 24 \mathrm{hr} / \mathrm{kg}$, respectively, before and after the oral dose.

The findings obtained from the L-tryptophan loading test revealed no evidence suggestive of a disturbed tryptophan metabolism due to vitamin $B_{6}$ deficiency. 


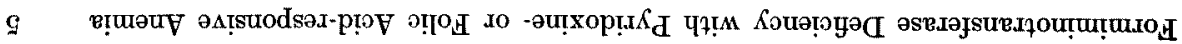


AICA loading test: ${ }^{6}$ Urinary excretion of AICA was found to be $0.13 \mathrm{mg} / \mathrm{kg} /$ day and $2.14 \mathrm{mg} / \mathrm{kg} /$ day before and after an oral dose of AICA, $20 \mathrm{mg} / \mathrm{kg}$ (June 1967), respectively. Urinary AICA after the oral dose was considered to be increased above the normal limit of $1.5 \mathrm{mg} / \mathrm{kg} /$ day.

No abnormality was found in any of glucose tolerance (June 1966), Moljodol (lipiodol) absorption (July 1966) and triiodothyronin uptake tests (July 1966).

Chromosomal analysis revealed a normal pattern in number and shape.

Histologic findings of the liver specimens obtained by surgical biopsy on Dec. 15, 1966 revealed hemosiderin deposits in hepatic cells and Kupffer's cells and round cell infiltration of slight degree in the portal tracts (cf. Fig. 1).

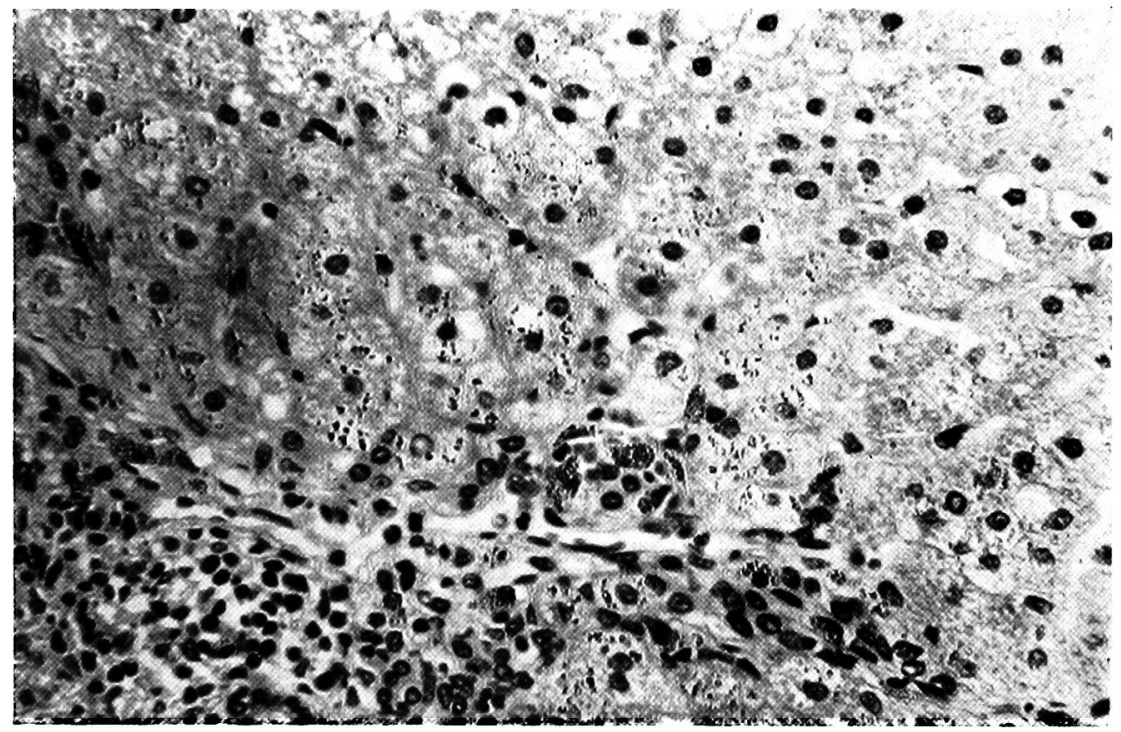

Fig. 1. Histologic findings of the liver of our own patient.

Urinary excretion of formiminoglutamic acid (FIGLU) after an oral dose of L-histidine monohydrochloride, $0.33 \mathrm{~g}$ per $\mathrm{kg}$ of bodyweight: Urinary excretion of FIGLU ${ }^{11}$ following the oral dose of L-histidine was found to be increased, ranging from 0.64 to $2.7 \mu$ moles per $\mathrm{ml}$ in spite of the presence of high serum folate levels over a period from January 1966 to September 1966. The increased excretion of FIGLU was more exaggerated during the period where serum folate turned to normal or subnormal levels after the patient had been placed on a low folate milk preparation (from September 29, 1966).

An administration of pyridoxal phosphate, 50-100 mg daily intramuscularly for consecutive 15 days, did not bring about any significant effect upon urinary excretion of FIGLU following an oral dose of histidine, showing urinary FIGLU ranging between $6.4 \mu$ moles $/ \mathrm{ml}(875 \mu$ moles $/ 8 \mathrm{hr}$ urine $)$ and $16.1 \mu$ moles $/ \mathrm{ml}(2,093$ $\mu$ moles $/ 8 \mathrm{hr}$ urine). On the other hand, after an intravenous administration of 
pteroylglutamic acid, $10 \mathrm{mg}$ daily for consecutive 8 days, urinary FIGLU following the oral dose of histidine was found to be markedly reduced to values of $0.395 \mu$ mole $/ \mathrm{ml}$ (100.7 $\mu$ moles $/ 8 \mathrm{hr}$ urine) (July 15, 1967), and $0.585 \mu$ mole/ml $(220.4 \mu$ moles/8 hr urine) (July 26, 1967), which were considered to be still above the upper limit of normal range $(0.1 \mu$ mole $/ \mathrm{ml}){ }^{12}$

Activities of tetrahydrofolate-dependent enzymes of the liver and erythrocytes: Liver specimens obtained by surgical biopsy were used for the assay of formiminotransferase, serine hydroxymethylase and $\mathrm{N}^{5}$ methyltetrahydrofolate transferase activities.

Erythrocyte lysate was used for the assay of $\mathrm{N}^{5,10}$ methylenetetrahydrofolate dehydrogenase, and formate activating enzyme activities.

Detailed procedures of each of these enzyme assays were the same as those described in previous papers of ours. ${ }^{13,14}$

TABLE 2. Formiminotransferase activity of the liver from our oun patient and controls

\begin{tabular}{|c|c|c|}
\hline & Subjects examined & $\begin{array}{l}\text { Formiminotransferase activity } \\
\text { of liver (m/ moles of } \mathrm{N}^{5,10} \mathrm{me} \text { - } \\
\text { thenyltetrahydrofolate per min } \\
\text { per mg of protein) }\end{array}$ \\
\hline 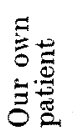 & $\begin{array}{l}\text { Y.M. Iy. 2m. } \\
\text { Formiminotransferase deficiency associated with } \\
\text { megaloblastic pyridoxine-folic acid-responsive } \\
\text { anemia }\end{array}$ & 5.7 \\
\hline 홀 & $\begin{array}{l}\text { K. U. } 2 \text { y. } 3: \mathrm{m} \text {. } \\
\mathrm{N} \text { methyltetrahydrofolate transferase deficiency } \\
\text { S.K. } 2 \text { y } 11 \mathrm{~m} \text {. } \\
\text { Mental retardation } \\
\text { S. H. } 1 \text { y. } 1 \mathrm{~m} \text {. } \\
\text { Hyperuricemia } \\
\text { I.E. } 2 \text { y. } 5 \mathrm{~m} \text {. } \\
\text { Mental retardation } \\
\text { Y.T. } 0 \text { y } 6 \mathrm{~m} \text {. } \\
\text { Mental retardation } \\
\text { K. T. } 0 \text { y } 7 \mathrm{~m} \text {. } \\
\text { Mental retardation } \\
\text { A. B. } 63 \text { y. } \\
\text { Cholelithiasis } \\
\text { K.E. } 60 \mathrm{y} \text {. } \\
\text { Gastric cancer } \\
\text { E.T. } 60 \mathrm{y} \text {. } \\
\text { Gastrie cancer }\end{array}$ & $\begin{array}{l}31.2 \\
24.8 \\
30.2 \\
18.1 \\
25.6 \\
18.3 \\
29.8 \\
25.2 \\
17.3\end{array}$ \\
\hline
\end{tabular}

As is shown in Tables 2-6, a marked decrease in formiminotransferase activity was observed on liver specimens obtained from our own patient, whereas other tetrahydrofolate dependent enzyme, such as serine hydroxymethylase, and $\mathrm{N}^{5}$ methyltetrahydrofolate-transferase of the liver specimens, and formate activating enzyme, and $N^{5.10}$ methylenetetrahydrofolate dehydrogenase of erythrocytes did not differ in their activities from those of controls. 
TABLE 3. $N^{5}$ methyltetrahydrofolate transferase activity of the liver from our own patient and controls

\begin{tabular}{|c|c|}
\hline Subjects examined & $\begin{array}{l}\mathrm{N}^{5} \text { methyltetrahydrofolate transferase } \\
\text { activity of liver (cpm of labeled } \\
\text { methionine per hour per mg of protein)* }\end{array}$ \\
\hline $\begin{array}{l}\text { Y. M. S. } 1 y .2 \mathrm{~m} \text {. } \\
\text { Formiminotransferase deficiency associated } \\
\text { with megaloblastic pyridoxine-folic acid- } \\
\text { responsive anemia }\end{array}$ & 2,094 \\
\hline $\begin{array}{l}\text { A. B. } 5.60 \mathrm{y} \text {. } \\
\text { Gastric cancer }\end{array}$ & 1,934 \\
\hline $\begin{array}{l}\text { C.K. \&. } 0 \text { y. } 1 \mathrm{~m} . \\
\text { Diaphragmatic hernia }\end{array}$ & 1,848 \\
\hline
\end{tabular}

TABLE 4. Serine-hydroxymethylase activity of the liver from our own patient and controls

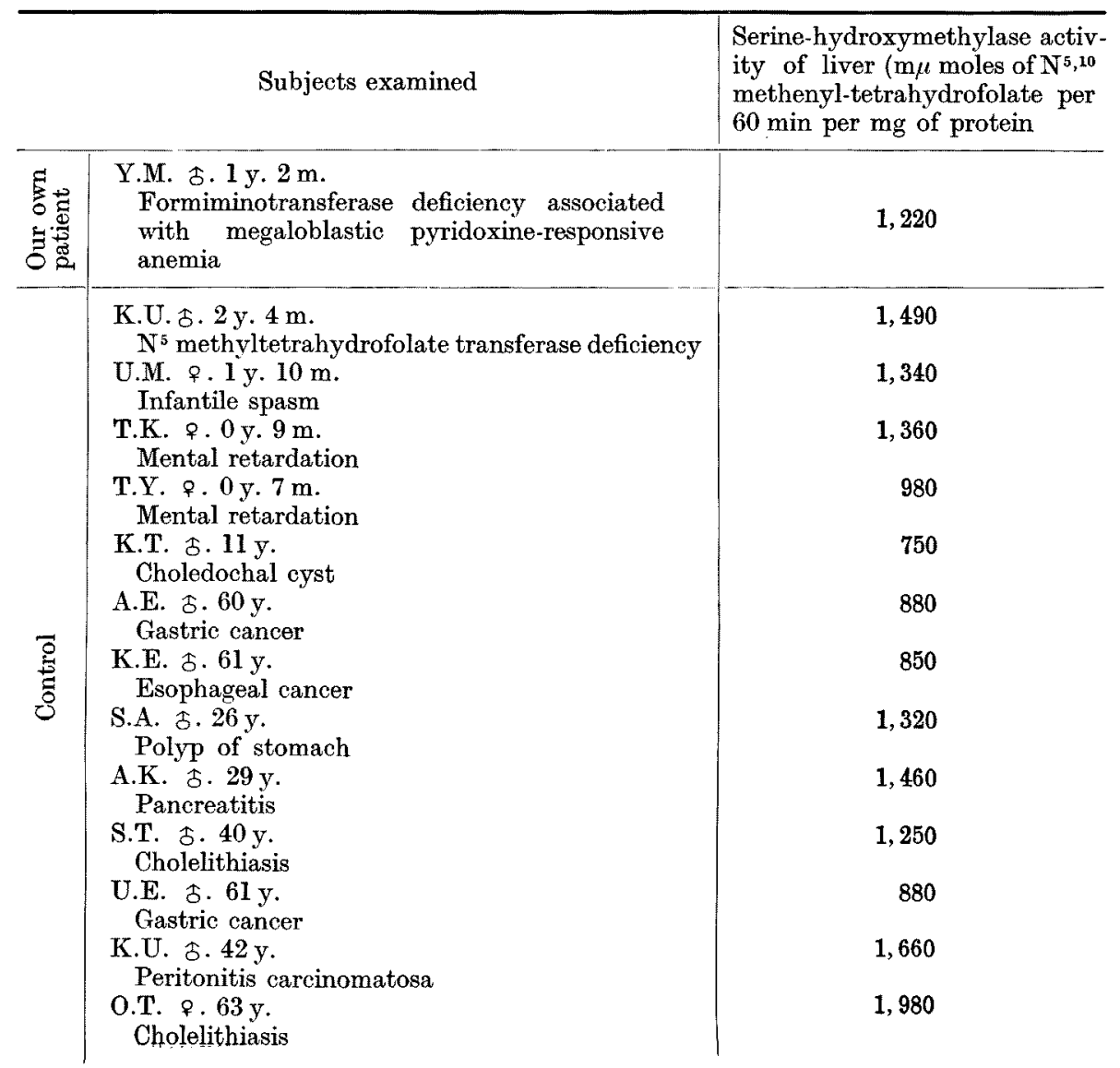


TABLE 5. Formate activating enzyme activity of erythrocytes from our own patient and controls

\begin{tabular}{|c|c|c|}
\hline & Subjects examined & $\begin{array}{l}\text { Formate activating enzyme } \\
\text { activity of erythrocytes (m } \mu \\
\text { mole of } \mathrm{N}^{5}, 10 \text { methenyl- } \\
\text { tetrahydrofolate per hour per } \\
\text { mg of hemoglobin) }\end{array}$ \\
\hline 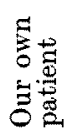 & $\begin{array}{l}\text { Y.M. } \delta .1 \text { y. } 2 \mathrm{~m} \text {. } \\
\text { Formiminotransferase deficiency associated with } \\
\text { megaloblastic pyridoxine-folic acidresponsive } \\
\text { anemia }\end{array}$ & 4.5 \\
\hline 旁 & $\begin{array}{l}\text { T.K. \&. } 1 \text { y. } 0 \mathrm{~m} \text {. } \\
\text { Mental retardation } \\
\text { S.Y. S. } 1 \text { y. } 0 \mathrm{~m} \text {. } \\
\text { Hyperuricemia } \\
\text { T.O. \&. } 1 \text { y. } 0 \mathrm{~m} \text {. } \\
\text { Failure of growth } \\
\text { U.M. \&. } 1 \text { y. } 0 \mathrm{~m} \text {. } \\
\text { Convulsions }\end{array}$ & $\begin{array}{l}6.3 \\
5.0 \\
4.2 \\
6.0\end{array}$ \\
\hline
\end{tabular}

TABLE $6 . \quad N^{5,10}$ methylenetetrahydrofolate dehydrogenase activity of erythrocytes from our oun patient and controls

\begin{tabular}{|c|c|c|}
\hline & Subjects examined & $\begin{array}{l}\mathrm{N}^{5,10} \text { methylenetetrahydrofolate } \\
\text { dehydrogenase activity ( } \mathrm{m} \mu \\
\text { mole of } \mathrm{N}^{5,10} \text { methenyltetra- } \\
\text { hydrofolate per hour per mg of } \\
\text { hemoglobin) }\end{array}$ \\
\hline 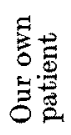 & $\begin{array}{l}\text { Y.M. o. } 1 \text { y. } 2 \mathrm{~m} \text {. } \\
\text { Formiminotransferase deficiency associated with } \\
\text { megaloblastic pyridoxine-folic acidresponsive } \\
\text { anemia }\end{array}$ & 17.7 \\
\hline & $\begin{array}{l}\text { T.O. \$. } 1 \text { y. } 0 \mathrm{~m} \text {. } \\
\text { Failure to thrive } \\
\text { T.K. } .1 \text { y. } 0 \mathrm{~m} \text {. } \\
\text { Mental retardation } \\
\text { K.G. \&. } 12 \mathrm{y} \text {. } \\
\text { Marfan's syndrome } \\
\text { S.Y. \$. } 1 \text { y. } 0 \mathrm{~m} \text {. } \\
\text { Hyperuricemia } \\
\text { U.M. \&. } 1 \text { y. } 0 \mathrm{~m} \text {. } \\
\text { Infantile spasm }\end{array}$ & $\begin{array}{r}15.2 \\
18.7 \\
21.3 \\
15.8 \\
6.0\end{array}$ \\
\hline
\end{tabular}

Electroencephalograms taken at the age of 5 months revealed no abnormality, but those at the age of 1 year 5 months showed a low voltage in frontal areas.

Pneumoencephalography carried out at the age of 1 year 5 months revealed that Evans' ratios were 0.34 on the right and 0.30 on the left side and the third ventricle was $8 \mathrm{~mm}$ in diameter, and that there was air accumulation suggestive of diffuse cortical atrophy of frontal areas (cf. Fig. 2).

At the age of 1 year 8 months the patient could walk with support but speak only a few words. 


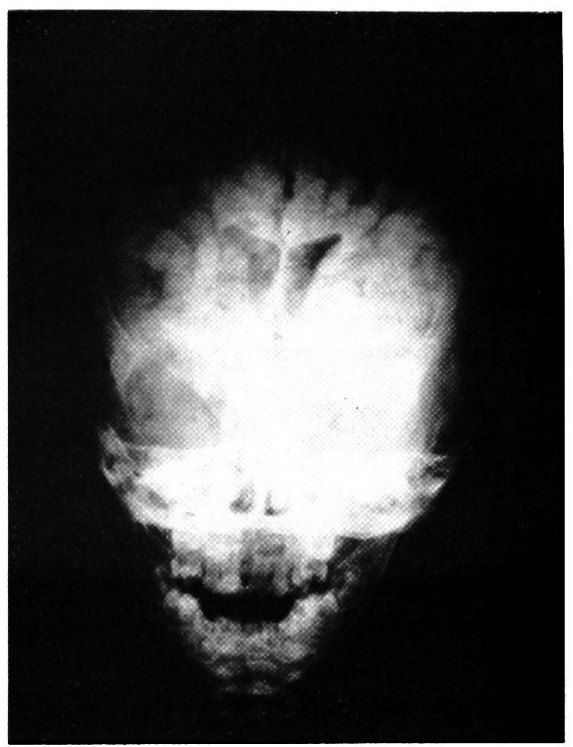

Fig. 2. Pneumoencephalogram of our own patient showed that Evans' ratio was 0.34 on the right, 0.30 on the left side, the third ventricle being $8 \mathrm{~mm}$ in diameter. There was air accumulation suggestive of cortical atrophy.

Serum vitamin $\mathrm{B}_{12}$ was estimated on March 1967 using L. leichmannii ATCC 4797 with a normal value of $0.93 \mathrm{~m} \gamma / \mathrm{ml}$.

Serum L. casei folate activity: Serum folate levels were found to be abnormally high, ranging from $57 \mathrm{~m} \gamma / \mathrm{ml}$ to $100 \mathrm{~m} \gamma / \mathrm{ml}$ during a period of from the early stage of his admission to September 1966, and fell down to normal and subnormal levels since November 20, 1966. This decrease in serum folate levels was considered to be due to a decrease in daily folate intake, because milk preparation which had been used until September 29, 1966 contained $38 \gamma$ of folic acid per $100 \mathrm{ml}$, but that used after September 30, 1966 was far less in the amount of folate than the former, containing only $8 \gamma$ per $100 \mathrm{ml}$ (cf. Table 1).

Estimation of folic acid in milk preparations was carried out in the same way as described by Naiman and Oski10 except that samples were diluted up to $1: 10$ with $0.1 \mathrm{M}$ phosphate buffer of $\mathrm{pH} 6.1^{8}$ containing $500 \mathrm{mg}$ of ascorbic acid per $100 \mathrm{ml}$, and were autoclaved at $121^{\circ} \mathrm{C}$ for $3 \mathrm{~min}^{8}$ or at $118^{\circ} \mathrm{C}$ for $10 \mathrm{~min} .^{9}$

Hematologic findings (cf. Table 7 and Fig. 3): After admission his anemia persisted and repeated blood transfusions were required to maintain his red cell counts appropriately, until pyridoxal phosphate was administered. The intramuscular injections of pyridoxal phosphate consisting of $100 \mathrm{mg}$ daily for 8 days and $50 \mathrm{mg}$ daily for next 7 days resulted in a remarkable increase in reticulocyte count and a gradual increase in erythrocyte count.

In bone marrow smears megaloblastoid cells and ringed sideroblasts were 


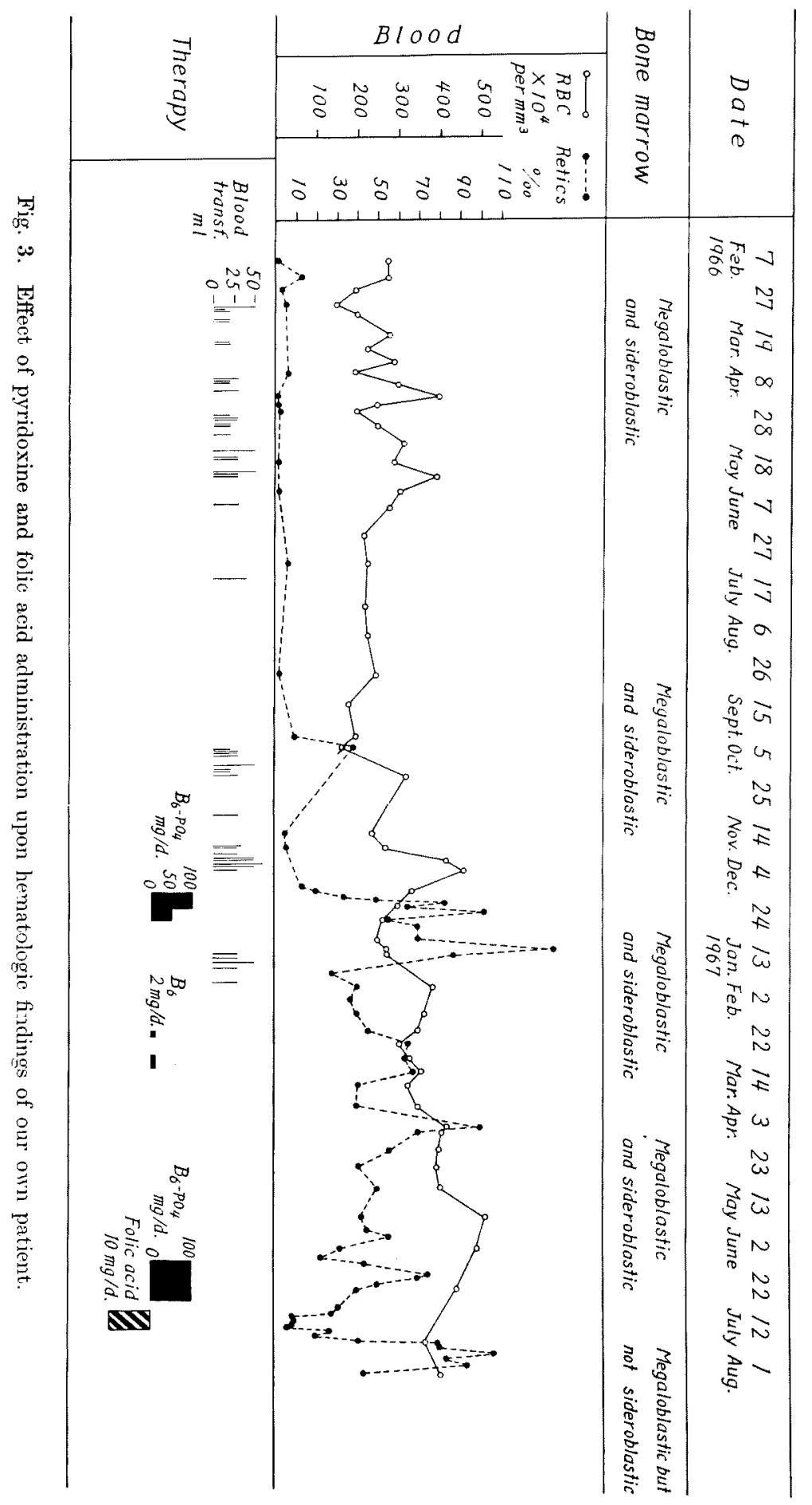

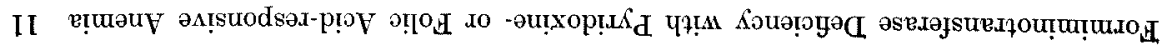


found on February 1, 1966, when the patient was 3 months old. After pyridoxine therapy, both megaloblastoid cells and ringed sideroblasts still persisted in the bone marrow smears examined on June 10, 1967 (cf. Table 7 and Fig. 3).

Folic acid was administered by intramuscular injections in a daily dose of 10 mg for consecutive 9 days, with a marked reticulocyte response (cf. Table 7 and Fig. 3). After the folic acid therapy, ringed sideroblasts decreased markedly in number (July 27, 1967), but megaloblastoid cells showed a slight decrease in number (cf. Table 7).

TABLE 7. The hematological

\begin{tabular}{|c|c|c|c|c|c|c|c|c|c|c|}
\hline Date & $\begin{array}{l}30 \\
\text { Nov. } \\
1965\end{array}$ & $\begin{array}{c}14 \\
\text { Dec. }\end{array}$ & \begin{tabular}{c|}
21 \\
Dec.
\end{tabular} & $\begin{array}{c}11 \\
\text { Jan. } \\
1966\end{array}$ & Feb. & $\underset{2}{2}$ & $\begin{array}{l}16 \\
\text { May }\end{array}$ & $\begin{array}{l}4 \\
\text { July }\end{array}$ & \begin{tabular}{|c|}
27 \\
Aug.
\end{tabular} & Oct. \\
\hline $\begin{array}{l}\text { Red cell count }\left(\times 10^{4} / \mathrm{mm}^{3}\right) \\
\text { Hemoglobin }(\mathrm{g} / 100 \mathrm{ml}) \\
\text { Hematocrit }(\%) \\
\text { MCV }\left(\mu^{3}\right) \\
\text { MCH }(\mu \mu \mathrm{g}) \\
\text { Reticulocytes }(\%) \\
\text { White cell count }\left(\text { per } \mathrm{mm}^{3}\right) \\
\text { Basophils }(\%) \\
\text { Eosinophils }(\%) \\
\text { Lymphocytes }(\%) \\
\text { Monocytes }(\%) \\
\text { Neutrophils }(\%) \\
\text { I } \% \text { ( II } \\
\text { III } \\
\text { IV } \\
\text { V } \\
\text { Platelets }\left(\times 10^{4} / \mathrm{mm}^{3}\right)\end{array}$ & $\begin{array}{c}228 \\
7.5 \\
23 \\
109 \\
32 \\
19 \\
7,500\end{array}$ & $\left\{\begin{array}{c}211 \\
7.6 \\
36 \\
7,100\end{array}\right.$ & \begin{tabular}{|c|}
203 \\
5.7 \\
20 \\
98 \\
28 \\
\\
3,000
\end{tabular} & \begin{tabular}{|c|}
240 \\
7.2 \\
22 \\
91 \\
30 \\
10
\end{tabular} & \begin{tabular}{|r}
278 \\
\\
23 \\
82 \\
\\
10 \\
10,800 \\
0 \\
1.0 \\
66. \\
3. \\
29. \\
28 \\
42 \\
28 \\
0 \\
2
\end{tabular} & \begin{tabular}{|c|}
228 \\
6.4 \\
26 \\
114 \\
28
\end{tabular} & \begin{tabular}{|c}
294 \\
9.4 \\
27 \\
91 \\
31 \\
1 \\
3,500 \\
1 \\
3 \\
67 \\
5 \\
24 \\
52 \\
38 \\
6 \\
4 \\
0 \\
3
\end{tabular} & \begin{tabular}{|c}
225 \\
8 \\
22 \\
97 \\
35 \\
7 \\
9,800 \\
0 \\
2 \\
54 \\
7 \\
37 \\
14 \\
68 \\
14 \\
4 \\
0 \\
54
\end{tabular} & \begin{tabular}{|c|}
200 \\
6.4 \\
18 \\
90 \\
31 \\
1 \\
4,200 \\
0 \\
1 \\
85 \\
2 \\
12
\end{tabular} & \begin{tabular}{|c}
161 \\
5.1 \\
18 \\
111.7 \\
31.6 \\
39
\end{tabular} \\
\hline Bone marrow findings & & & & & $\begin{array}{l}\text { Feb. I } \\
1966\end{array}$ & $\begin{array}{l}\text { Mar. } \\
1966\end{array}$ & & & $\begin{array}{r}\text { Sept } \\
19\end{array}$ & $\begin{array}{l}\text { t. } 29 \\
966\end{array}$ \\
\hline $\begin{array}{l}\text { per } 100 \text { erythroblasts } \\
\text { per } 100 \text { proerythro- } \\
\text { blasts } \\
\text { Sideroblasts }\end{array}$ & & & & & $\begin{array}{l}25 \\
62\end{array}$ & & $\begin{array}{r}8 \\
56\end{array}$ & & & $\begin{array}{r}6 \\
43\end{array}$ \\
\hline $\begin{array}{l}\text { total, per } 100 \text { erythro } \\
\text { blasts }\end{array}$ & & & & & 81 & & 96 & & & 88 \\
\hline $\begin{array}{l}\text { ringed sideroblasts, } \\
\text { per } 100 \text { erythroblasts }\end{array}$ & & & & & 23 & 1. & 12 & & & 30 \\
\hline $\begin{array}{l}\text { Total nucleated cell count, } \\
\text { per } \mathrm{mm}^{3}\end{array}$ & & & & & 69,000 & 151,00 & & & 43, & 000 \\
\hline$M: \bar{E}$ ratio & & & & & $1.7: 1$ & $6:$ & & & 3.6 : & $: 1.0$ \\
\hline
\end{tabular}

\section{Discussion}

The disease presented herein was diagnosed as a case of formiminotransferase deficiency syndrome, because of the presence of abnormal high levels of serum $L$. casei activity, abnormally large amount of urinary FIGLU following an oral 
load of L-histidine and a marked decrease in formiminotransferase activity of the liver.

Up to date cases of formiminotransferase deficiency with a definite diagnosis were only two cases $^{1,2}$ in our experience and the present case is the third of this syndrome where a defective activity of formiminotransferase of the liver was established definitely.

As compared with elinical manifestations of the previous two cases of formiminotransferase deficiency syndrome reported by us, the present case differed

data of the present case

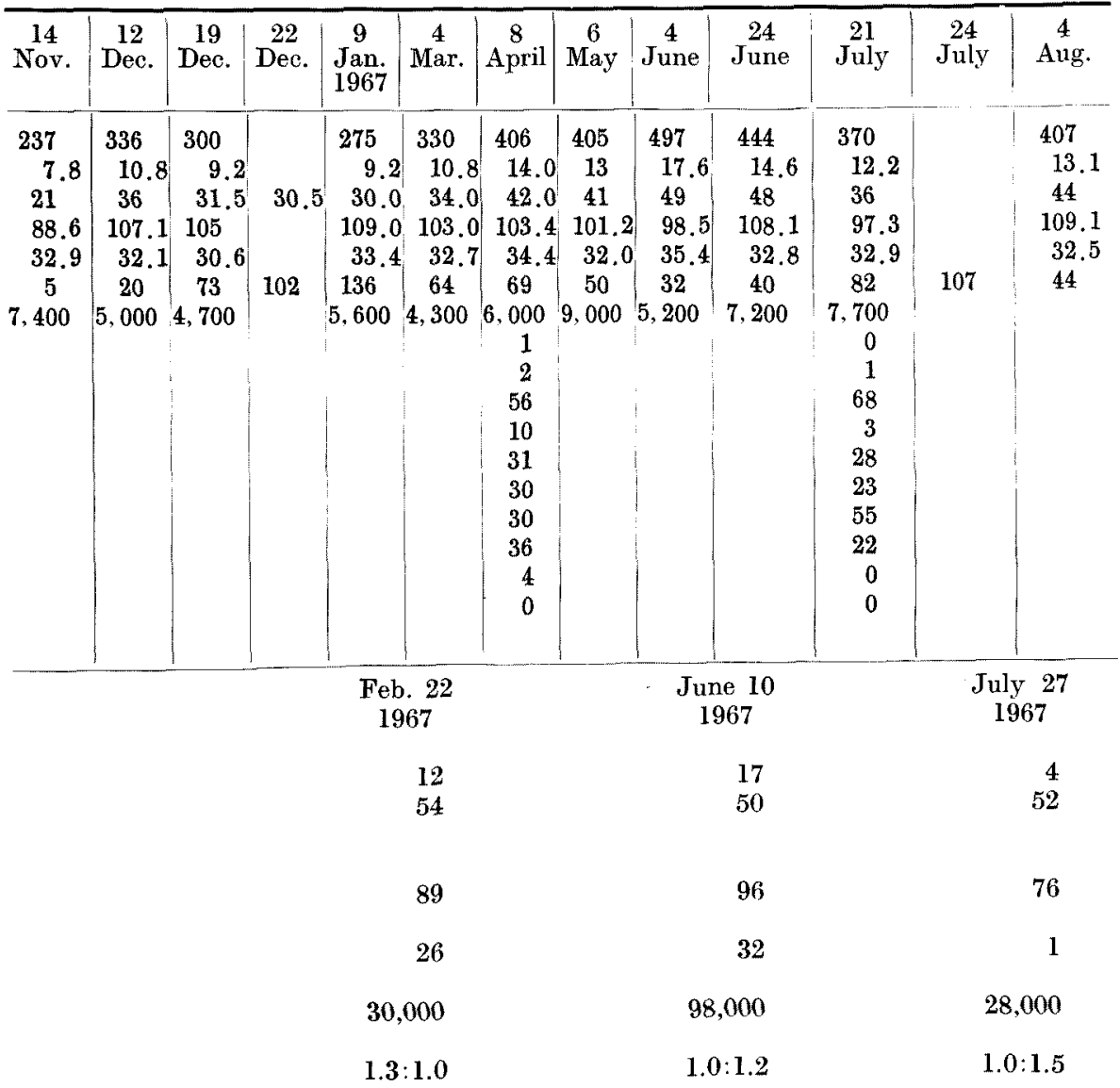

from the former two in that megaloblastic-pyridoxine-folic acid-responsive anemia appeared as one of prominent clinical manifestations and that mental retardation of the present case was much less in degree even though dilatation of cerebral ventricles and cortical atrophy were demonstrated in pneumoencephalograms.

In the present case of formiminotransferase deficiency a hematological 
diagnosis was made of sideroblastic-megaloblastic and pyridoxine-folic acidresponsive anemia ${ }^{15,16}$ of probably congenital origin basing upon following findings:

1) An anemia was found soon after birth and both ringed-sideroblasts and megaloblastoid cells were found in bone marrow smears examined at the age of 3 months, 2) after pyridoxine administration, a remarkable rise in reticulocyte count followed by an increase in erythrocyte count ensued, but megaloblastoid cells and ringed-sideroblasts still persisted in bone marrow smears repeatedly examined thereafter, and 3) there was no increase in urinary excretion of xanthurenic acid following an oral loading of tryptophane which was carried out before pyridoxine administration was instituted.

A congenital occurrence of pyridoxine-responsive megaloblastic anemia does not seem to have appeared in the literature so far. In 1964 Horrigan and Harris ${ }^{17}$ published a detailed report of analysis of 62 cases of pyridoxine-responsive anemia, in which the cases with normoblastic erythropoiesis were found in 48 cases, those with undetermined bone marrow pictures in 4 cases and those with megaloblastic erythropoiesis in 10 cases. Among the 10 cases of megaloblastic erythropoiesis no case of congenital onset was recorded, whereas 3 cases of congenital onset were recorded among 48 cases with normoblastic erythropoiesis, and also one congenital onset was recorded among 4 cases with undetermined bone marrow findings.

At the present time it remains obscure whether the association of formiminotransferase deficiency with the development of sideroblastic-pyridoxine-responsive anemia is significant or only coincidental.

On assuming that formiminotransferase deficiency and sideroblastic-megaloblastic-pyridoxine responsive anemia observed in our own patient are of significant association, if any, with one another in their pathogenesis, the following two possibilities might be evaluated for an explanation of the association.

a) The first is that formiminotransferase deficiency is a primary congenital lesion of our own patient and that it leads to subsequent development of sideroblastic-megaloblastic pyridoxine-responsive anemia. This assumption is derived from the reason that a defective activity of formiminotransferase gives rise to an impaired utilization of folic acid, that is, 'functional deficiency's of folates available for hematopoiesis, thus leading to development of megaloblastic changes in the bone marrow, and the resulting impaired hematopoiesis induces an elevation in serum iron levels, ${ }^{19,20}$ the latter leading to an increase in incidence of sideroblasts in the bone marrow. ${ }^{21}$ As an evidence supporting this conception, it may be worthy to note that ringed-sideroblasts observed in the bone marrow smears were markedly reduced in number after the folic acid therapy was instituted in our own patient (cf. Table 7 ).

In our present case of formiminotransferase deficiency, a marked rise in reticulocyte count was observed after the pyridoxine administration. An explanation for this is that pyridoxine given in large doses exerts an accelerating effect, if any, upon the serine hydroxymethylase reaction, thus resulting in an increased 
yielding of $\mathrm{N}^{5,10}$ methylenetetrahydrofolate available for hematopoiesis. In our case of formiminotransferase deficiency, however, serine hydroxymethylase activity of the liver was found to be normal (cf. Table 4).

As for the relationship between folate metabolism ${ }^{23}$ and sideroblastic anemia, MacGibbon and Mollin ${ }^{16}$ made a detailed investigation upon 70 cases of sideroblastic anemia and concluded that folic acid deficiency, the diagnosis of which was based upon the results of serum folate assay and urinary FIGLU test, was found in many cases of sideroblastic anemia and that this folate deficiency resulted from an increased requirement of folic acid in many diseases associated with sideroblastic anemia.

b) The second is such a possibility that formation and/or function of formiminotransferase system may be dependent on pyridoxine in a similar way, as the anemia of our own patient is pyridoxine responsive. This speculation may arise from the results reported by Vitale et $a l .{ }^{22}$ on one hand and those reported by Harris ${ }^{23}$ on the other; in 1966, Vitale et $a l$. found that formiminotransferase of the liver was markedly decreased in rats with iron deficiency and suggested a possibility of requirement of iron for function and/or formation of formiminotransferase system; in 1964, Harris investigated the role of pyridoxine in heme biosynthesis of two adult cases of megaloblastic-pyridoxine-responsive anemia and concluded that pyridoxine was necessary for release of heme from mitochondria of reticulocytes taken from these patients before pyridoxine therapy was instituted.

In our own patient, both pyridoxine responsive anemia and formiminotransferase deficiency were demonstrated from early infancy, so a question may arise whether or not an impaired utilization of iron due to pyridoxine dependency is a causative factor common to both defective activity of formiminotransferase and pyridoxine-responsive anemia.

This possibility turned to be unlikely from the experimental result recently obtained by Tamura ${ }^{14}$ of our Laboratory that formiminotransferase activity of the liver was not decreased in mice with pyridoxine deficiency induced by desoxypyridoxine or dietary deficiency.

\section{References}

1) Arakawa, Ts., Ohara, K., Kudo, Z, Tada, K., Hayashi, T. Mizuno, T. Hyperfolic acidemia with formiminoglutamic aciduria following histidine loading suggested for a case of congenital deficiency in formiminotransferase. Toholu J. exp. Med., 1963, 80, $370-382$.

2) Arakawa, Ts., Ohara, K., Takahashi, Y., Ogasawara, J., Hayashi, T., Chiba, R., Wada Y., Tada, K., Mizuno, T., Okamura, T. \& Yoshida, T. Formiminotransferase deficiency syndrome: A new inborn error of folic acid metabolism. Ann. paediat., 1965, $205,1-11$.

3) Heiskell, C.L., Fisk, R.T., Florshein, W.H., Tachi, A., Goodman, J.J. R. \& Carpenter, C.M. A simple method for quantitation of serum beta-lipoproteins by means of the immunocrit. Amer. J. clin. Path., 1961, 35, 222-226.

4) Price, J.M. The determination of $N$-methyl-2-pyridone-5-carboxamide in human urine. J. biol. Chem., 1954, 211, 117-124. 
5) Glazer, H.S., Mueller, J.F., Thompson, C., Haskins, V.R. \& Vilter, R.W. A study of urinary excretion of xanthurenic acid and other tryptophan metabolites in human being with pyridoxine deficiency induced by desoxypyridoxine. Arch. Biochem., 1951, $33,243-251$.

6) Arakawa, Ts. \& Wada, Y. Urinary AICA following an oral dose of AICA in formiminotransferase deficiency syndrome. Tohoku J. exp. Med., 1966, 88, 99-102.

7) Vitamin B Committee of Japanese Society of Vitaminology. Method for estimation of blood vitamin $\mathrm{B}_{12}$. Vitamins (Jap.), 1960, 19, 438-446.

8) Spray, G.H. Microbiological assay of folic acid activity in human serum. $J$. clin. Path., 1964, 17, 660-665.

9) Herbert, V. The assay and nature of folic acid activity in human serum. J. clin. Invest., 1961, 40, 81-91.

10) Naiman, J.L. \& Oski, F.A. The folic acid content of milk: Revised figures based on an improved assay method. Pediatrics, 1964, 34, 274-276.

11) Tabor, H. \& Wyngarden, L. The enzymatic formation of formiminotetrahydrofolic acid, 5, 10 methenyltetrahydrofolic acid, and 10 formyltetrahydrofolic acid in the metabolism of formiminoglutamic acid. J. biol. Chem., 1959, 234, 1830-1846.

12) Arakawa, Ts., Ohara, K., Fujii, M., Hirata, K. \& Takahashi, Y. Serum folate acivity and urinary formiminoglutamic acid following histidine load in infants and children. Tohoku J. exp. Med., 1965, 87, 199-204.

13) Arakawa, Ts., Narisawa, K., Tanno, K., Ohara, K., Higashi, O., Honda, Y., Tamura, T., Wada, Y., Mizuno, T. \& Hayashi, T. Megaloblastic anemia and mental retardation with hyperfolic acidemia: Probably due to $\mathrm{N}^{5}$ methyltetrahydrofolatetransferase deficiency. Tohoku $J$. exp. Med., 1967, 93, 1-22.

14) Tamura, T. Formiminotransferase activity of the liver from mice with pyridoxine deficiency. Tohoku J. exp. Med., 1967, 93, 377-379.

15) Mollin, D.L. Sideroblasts and sideroblastic anemia. Brit. J. Haemat., 1965, 11, $41-48$.

16) MeGibbon, B.H. \& Mollin, D.L. Sideroblastic anemia in man; observations on 70 cases. Brit. J. Hoxemat., 1965, 11, 59-69.

17) Horrigan, D.L. \& Harris, J.W. Pyridoxine-responsive anemia: Analysis of 62 cases. Advanc. intern. Med., 1964, 12, 103-174.

18) Herbert, V. The Pharmacological Basis of Therapeutics, edited by Goodman, L.S. and Gilman, A., 3rd ed., Macmillan Co., New York., 1965, p. 1410.

19) Giles, C. An account of 335 cases of megaloblastic anemia of pregnancy and the puerperium. $J$. clin. Pathol., 1966, 19, 1-11.

20) Metz, J., Turchetti, L., Combrink, B. \& Krawitz, S. Significance of tests of iron nutrition in pregnancy. J. clin. Pathol., 1966, 19, 173-176.

21) Morse, W.I. Stainable ferric iron particles in erythroid marrow cells and erythrocytes. Canad. med. Ass. J., 1955, 72, 418-426.

22) Vitale, J.J., Restreps, A., Vilez, H., Richer, J.B. \& Hellerstein, E.E. Secondary folate deficiency induced in rats by dietary iron deficiency. $J$. Nutr., 1966, 88, 315-322.

23) Harris, J.W. Notes and comments on pyridoxine-responsive anemia and the role of erythrocyte mitochondria in iron metabolism. Medicine, 1964, 43, 803-806. 